\title{
Research of risk management system on power supply enterprise
}

\author{
Xue Zhenyu ${ }^{1, a}$, Liu Haibo ${ }^{1, b}$, Huang Xin ${ }^{2, c}$ \\ ${ }^{1}$ State Power Economic Research Institute, China, 102206 \\ ${ }^{2}$ North China Electric Power University, Beijing 102206, China

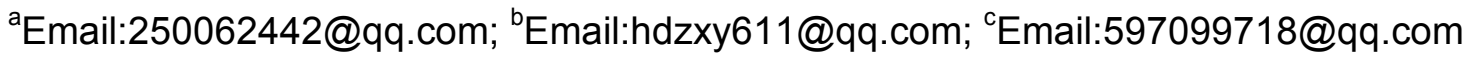

Keywords: risk management, internal risk, external risk, ISM

Abstract. By proposing conceptual model of power supply company management model, on this basis, paper summed up the internal and external risks of power supply company, and summed up the relationship between risk, after that the use of explaining the structural model, to tease out the risk system architecture of power supply company, provides a theoretical basis for the construction of the power supply enterprise risk management system and risk strategies, and establish risk measurement structure model.

\section{Introduction}

After 30 years of reform and opening up, Chinese market economic system is gradually improving, integration with the world economy continues to depth. However, attendant operational risks of enterprises have gradually increased. Enterprise-wide risk management theory for the first time have been proposed in the United States since the 1930s, after nearly 80 years of development, have become more mature, have been recognized more and more countries and companies. In order to improve the anti-risk ability, comprehensive risk management as an important means of prevention of risk is more and more enterprise applications to manage the actual being.

In recent years, foreign research on electricity market risk management is gradually improving, and achieved some results, and more and more researchers use general risk management theory to study risk management of the electric power market. G.Anders emphasized to introduce the theory of power market risk management, puts forward the electricity market risk management research must be carried out quantitative research ${ }^{[1]}$. R.Dahlgren divided the electricity market risk management related literature into seven categories, including: general risk assessment concepts, methods of hedging, market analysis and market operation so on ${ }^{[2]}$. Rudnick $\mathrm{H}$ et al. Proposed a kind of research methods about electricity transmission and distribution price, namely the postage stamp method ${ }^{[3]}$. Christie R D et al. Studied the optimal matching of supply and demand and transmission pricing methods, and put forward the reasonable share of transmission cost based on the distance ${ }^{[4]}$.

In this paper, by using interpretative structural modeling technology $\mathrm{y}^{[5]}$, test and optimize of risk index system, build the risk model for power supply enterprises, identify 23 risk factors. Through the identification of risk, and ultimately determine the risk of power supply mainly exist.

\section{Conceptual model of power supply enterprise business model}

The electric power market Economic relations system can be divided into two related subsystem: infrastructure services subsystem ${ }^{[6]}$ and energy trading subsystem ${ }^{[7]}$. The infrastructure services system including power transmission and distribution services, namely firstly acceptance the electric power generation enterprise online of power, secondly through the network transmission, finally the electric power distribution to the end user, which is the basis for achieving Energy flows of infrastructure services subsystem and energy trading subsystem; accordingly, the power grid enterprises in accordance with the certain price rules, charge a fee to generation enterprises and power generation companies dealers through the network, which is achieving currency flows between infrastructure services subsystem and energy trading subsystem. The required costs of grid stability 
have been included among wheeling cost or terminal price. Therefore, according to the provisions of power purchase contracts, power supply enterprise has a responsibility to ensure the reliability of the power generation companies to transport users, and to bear the financial responsibility for the power transmission is interrupted. Power supply enterprise have grid, the business has a natural monopoly. Power grid Dealers may not necessarily have the power grid assets, but it is necessary that collect and save the end-user electricity demand information and quite understand on the generation side of the market, so that you can purchase power in the form of generation market in the wholesale power market, and sale to end user in the retail market, sale power to earn a profit. This is a business model of perfectly competitive market, as shown in Fig.1. If a business enterprise, including transmission and distribution companies and electricity distributors, this enterprise can operate both transmission and distribution network and the sale of electricity. Chinese current electricity market would fall into this category, as shown in Fig.2.

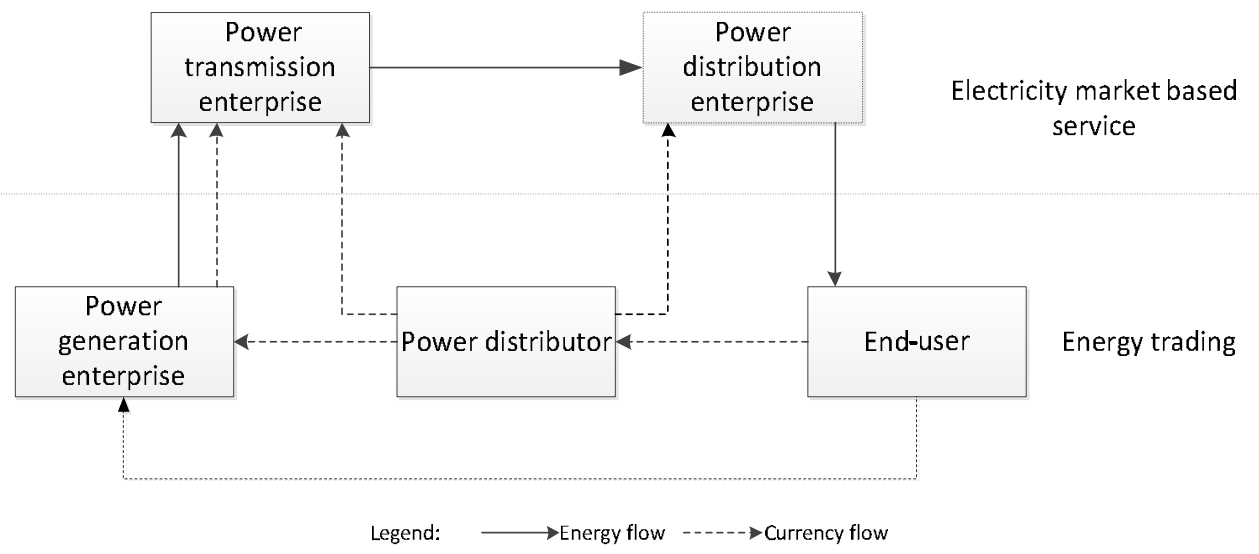

Fig.1 Conceptual model of the power supply enterprise in perfect competition

economic environment Legal and policy environment natural environment credit environment

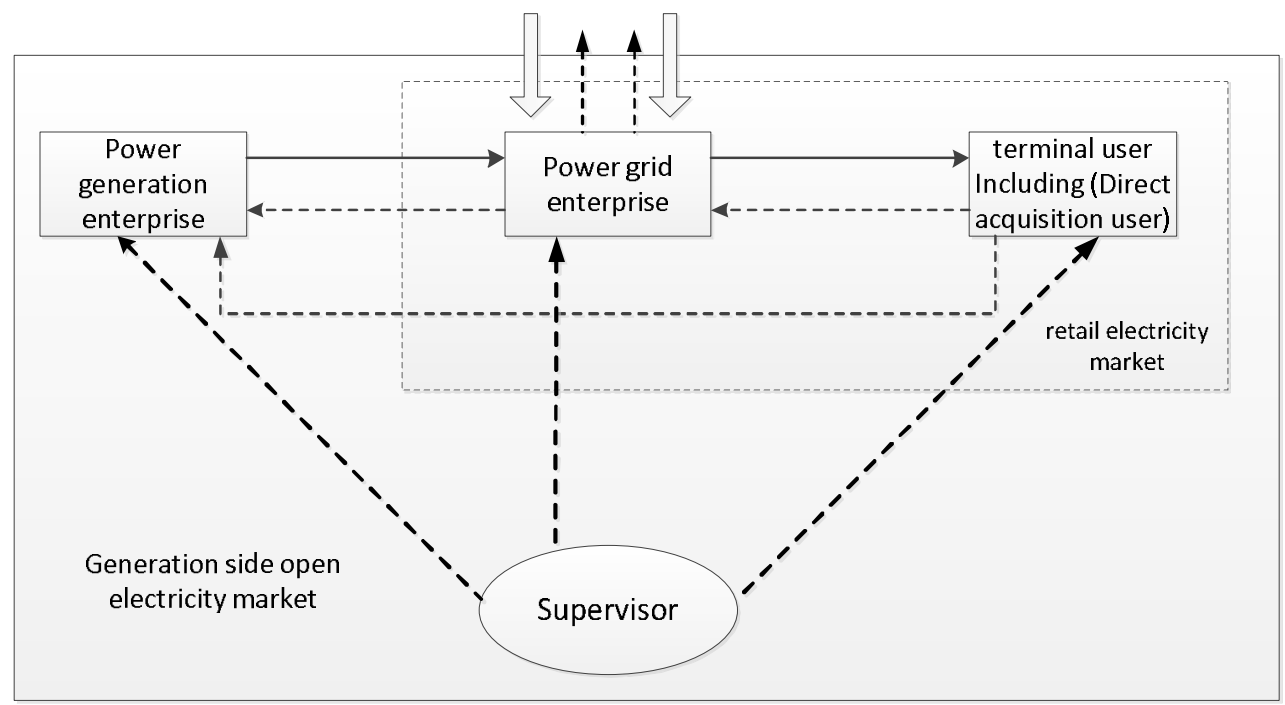

Legend: $\longrightarrow$ Energy flow $---\rightarrow$ Currency flow $--\rightarrow$ Supervision route

Fig.2 Power supply business environment conceptual model

\section{Supply enterprise risk factor interaction analysis}

In accordance with the power supply enterprise internal and outside risk the and its unique risk ${ }^{[8]}$, in conjunction with Figure 1 and Figure 2 reflected in the electricity market risk environment, we can get the power supply enterprise risk and its influence factors set, list in Table 1. 
Table. 1 power supply enterprise risk and risk factors

\begin{tabular}{|c|c|c|c|}
\hline $\begin{array}{c}\text { Serial } \\
\text { number }\end{array}$ & $\begin{array}{l}\text { Risk and risk } \\
\text { factors }\end{array}$ & Descriptive definition & $\begin{array}{l}\text { direct } \\
\text { affect } \\
\text { Factor }\end{array}$ \\
\hline 1 & Natural risk & $\begin{array}{l}\text { Due to severe casualties and equipment damage directly } \\
\text { caused by natural disasters, resulting in power supply } \\
\text { enterprise the loss of profits and assets. }\end{array}$ & $\begin{array}{l}7,14 \\
17 \\
11,12\end{array}$ \\
\hline 2 & $\begin{array}{l}\text { Macroeconomic } \\
\text { risk }\end{array}$ & $\begin{array}{l}\text { Since the state policies changes of the electricity enterprise in } \\
\text { lending and investing, fluctuations of interest rates and } \\
\text { exchange rate in the financial markets etc., affect the } \\
\text { company's production operations. }\end{array}$ & 7,14 \\
\hline 3 & Social risk & $\begin{array}{c}\text { Due to fluctuations and change of economic political cultural } \\
\text { and other factors in the social have an impact on enterprises } \\
\text { engaged in production. }\end{array}$ & 8 \\
\hline 4 & $\begin{array}{l}\text { policies and } \\
\text { regulations Risk }\end{array}$ & $\begin{array}{l}\text { Adjustments and changes of policies and regulations on } \\
\text { electricity generation business risk management, } \\
\text { administration and economic. }\end{array}$ & $\begin{array}{l}8,13 \\
14 \\
15 \\
16,19\end{array}$ \\
\hline 5 & Technical risk & $\begin{array}{l}\text { Due to technological advances, or technical flaws caused the } \\
\text { loss in the security stability and management of power supply } \\
\text { enterprise }\end{array}$ & $\begin{array}{l}9,10 \\
11,13\end{array}$ \\
\hline 6 & Weather Risk & $\begin{array}{l}\text { Weather change can greatly affects the load change, boring } \\
\text { risks about maintenance and safe operation }\end{array}$ & $\begin{array}{l}9,10 \\
11,12\end{array}$ \\
\hline 7 & Financial risk & $\begin{array}{l}\text { Due to the financial structure or financing is unreasonable } \\
\text { and improper, company may lose the solvency to lead to the } \\
\text { risk that investors expect earnings decline }\end{array}$ & \\
\hline 8 & $\begin{array}{l}\text { Organizational } \\
\text { risk }\end{array}$ & $\begin{array}{c}\text { Due to ring true enterprise department set is unreasonable, } \\
\text { between departments coordination is not smooth to cause } \\
\text { Risks }\end{array}$ & 11,22 \\
\hline 9 & $\begin{array}{l}\text { Construction } \\
\text { risk }\end{array}$ & $\begin{array}{l}\text { Including the risk of construction materials, security, } \\
\text { schedule costs and quality }\end{array}$ & $\begin{array}{c}7,10 \\
11\end{array}$ \\
\hline 10 & Repair risk & $\begin{array}{c}\text { Uneconomical and unreasonable Repair result losses in safe } \\
\text { operation and the financial }\end{array}$ & $\begin{array}{c}7,11 \\
18\end{array}$ \\
\hline 11 & Safe operation & $\begin{array}{c}\text { Existence of security risks constituted the threat of power } \\
\text { enterprises }\end{array}$ & 7,18 \\
\hline 12 & $\begin{array}{l}\text { The maximum } \\
\text { load duration }\end{array}$ & $\begin{array}{l}\text { The uncertainty of maximum load duration brought rise of to } \\
\text { the power company's cost and safe operation }\end{array}$ & $\begin{array}{l}11, \\
18,21\end{array}$ \\
\hline 13 & Trading patterns & $\begin{array}{l}\text { Different trading patterns bring a different risk to the market } \\
\text { theme and bring a lot of uncertainty in price ,controls and } \\
\text { trading }\end{array}$ & $\begin{array}{l}7,11 \\
14 \\
15 \\
16 \\
19,20\end{array}$ \\
\hline 14 & $\begin{array}{l}\text { Purchase price } \\
\text { risk }\end{array}$ & $\begin{array}{c}\text { According to the competition relationship got the average } \\
\text { purchase price In the power generate market }\end{array}$ & 7 \\
\hline 15 & Price controls & $\begin{array}{l}\text { Price regulation brought about a lot of uncertainty to the } \\
\text { power grid enterprise operation and profitability }\end{array}$ & 7,16 \\
\hline 16 & $\begin{array}{l}\text { The risk of the } \\
\text { user cost } \\
\text { allocation } \\
\text { calculations }\end{array}$ & $\begin{array}{l}\text { The characteristics of the power supply cost depends largely } \\
\text { on the user's power, influence of the fixed and variable cost }\end{array}$ & 7 \\
\hline 17 & $\begin{array}{l}\text { Uncertain factor } \\
\text { grid planning }\end{array}$ & $\begin{array}{l}\text { Power grid planning is facing a lot of uncertain market } \\
\text { factors result in the uncertainty of power grid planning }\end{array}$ & $\begin{array}{l}7,9 \\
10 \\
11 \\
18,21\end{array}$ \\
\hline 18 & $\begin{array}{l}\text { Transmission } \\
\text { congestion }\end{array}$ & $\begin{array}{l}\text { Blocked will lead to the situation that the power grid } \\
\text { company will be forced to change purchase of electricity } \\
\text { plans, and buy expensive electricity from no blocking area, } \\
\text { resulting in increased power purchase costs }\end{array}$ & 11,21 \\
\hline
\end{tabular}




\begin{tabular}{|c|c|c|c|}
\hline 19 & $\begin{array}{c}\text { Perform } \\
\text { time-tariff } \\
\text { classification }\end{array}$ & $\begin{array}{l}\text { Perform time-tariff classification may bring financial loss to } \\
\text { supply enterprise }\end{array}$ & $\begin{array}{c}7,12 \\
16\end{array}$ \\
\hline 20 & $\begin{array}{l}\text { Power } \\
\text { generation } \\
\text { market }\end{array}$ & $\begin{array}{c}\text { Multiple power generation companies combination } \\
\text { deliberately raise electricity generation side constituted a } \\
\text { threat }\end{array}$ & 7,14 \\
\hline 21 & $\begin{array}{l}\text { Inadequate } \\
\text { supply of } \\
\text { ancillary } \\
\text { services }\end{array}$ & $\begin{array}{l}\text { The lack of auxiliary service supply can easily lead to the safe } \\
\text { and stable operation of power grid. }\end{array}$ & 11 \\
\hline 22 & User's credit risk & $\begin{array}{c}\text { Because users are unwilling or unable to repay the debt } \\
\text { caused losses }\end{array}$ & 7 \\
\hline 23 & $\begin{array}{l}\text { Local } \\
\text { government } \\
\text { policy }\end{array}$ & $\begin{array}{l}\text { The local government's policy may affect the power supply } \\
\text { enterprise business income }\end{array}$ & $\begin{array}{l}12,14 \\
20\end{array}$ \\
\hline
\end{tabular}

Table 1 defines the 23 kinds of risk, not only occur in risks caused by the electricity market variable itself, but also occurs in the generation, transmission, and service production and management processes. Power supply enterprises are faced with all economic uncertainty have been included in the risk. However, due to the causes of risk is complex, can't list them all. The table lists the corresponding influence factors, have been elements combination of supply enterprise risk system $N=\{1,2,3, \cdots, 23\}$ and directly affect the relationship.

\section{Analysis of examples}

There is a direct relationship between the 23 variables, which can be expressed as follows adjacency matrix.

Reachability matrix $\mathrm{M}$ as required of interpretation structure model application method, the rows and rows in ascending order, and in turn divided into order principal submatrix of largest unit, the results shown in Table 3.

The main conclusions of hierarchical structure directed graph and ISM risk model

According to the matrix shown in Table 3, in accordance with the practical method of Interpretative Structural Modeling draw the hierarchical structure directed graph in Figure 3.

\section{Conclusion}

By building supply enterprise risk system structure hierarchical diagram, combined with the risk classification, we can get the following conclusions:

(1) All of the risks and factors that have an impact on the financial risk through different ways and means;

(2) If you only consider the 4th floor, it formed four separate areas: Risk 15 (price control risk), 11 (the risk of the safe operation caused) risk, risk 2 (macroeconomic risks), the risk of 20 (power generation market risks);

(3) In this risk system, some risk are the source of risk for the power companies, some risk is only an impact on other risks, not affected by other risks;

(4) Although risk factor of exogenous isn't a risk itself, but it is the original birthplace of the power market risk, so to ensure stable operation of the power supply enterprise, not only to strengthen the direct management of risks, and serious study more for the business survival environment, the external market environment, the external economic environment, legal and policy environment, and the natural environment. 


\section{References}

[1] G.Anders,R.Entriken,P.Nitu . Risk assessment and financial management tutorial. Proc. of IEEE Power Eng. Soc. Winter Meeting, 1999, TP-137-0

[2] R.Dahlgren, C. C. Liu, J. Lawarree. Risk assessment in energy trading. IEEE Trans on Powr Systems,2003, 18(3): 503-511.

[3] Rudnick H, Franco N, Hammons T J, et al. Latin American deregulation processes[J]. IEEE Power Engineering Review, 1998,18(2):10-23.

[4] Christie R D, Wangensteen I. The energy market in Norway and Sweden: Introduction[J]. IEEE Power Engineering Review, 1998,18(2):44-45.

[5] Wang Wanqiu, Zhang Yong'an. Research on Factors Influencing Technology-Based Mergers and Acquisitions Synergy [J]. Science of Science and Management of S.\& T, 2009,04:104-109+193.

[6] Yin Hongxu , Lv Fenfei , Liu Nian, Zhang Jianhua, Cause and Case Analysis of Impact of Network Attacks on Electric Power Infrastructure[J]. Electric Power Information Technology, 2013,05:1-8.

[7] Wu Yang, Liu Junyang, Xu Lixiong, Yan Zhanxin, Zhang Li. An Evaluation Model of Power Transaction Strategy Based on Supply Channel Adequacy[J]. Power \& Energy, 2014,03:247-253.

[8] Fan Jixin. Research of power supply enterprise risk management under information environment[D]. The North China Electric Power University, 2012. 